\title{
West Nile Virus: A reemerging global pathogen.
}

\author{
History of the Medicine
}

Lyle R. Petersen ${ }^{1}$, John T. Roehrig ${ }^{2}$.

${ }^{1}$ Deputy Director for Science, Division of Vector-Borne Infectious Diseases, Centers for Disease Control and Prevention. ${ }^{2}$ Chief of the Arbovirus Diseases Branch, Division of Vector-Borne Infectious Diseases, Centers for Disease Control and Prevention. Fort Collins, Colorado, USA.

\section{SUMMARY.}

The recognition of West Nile (WN) virus in the Western Hemisphere in the summer of 1999 marked the first introduction in recent history of an Old World flavivirus into the New World. WN virus, a member of the family Flaviviridae (genus Flavivirus) was first isolated in 1937 in the West Nile district of Uganda. Since the original isolation of WN virus, outbreaks have occurred infrequently in humans, those in Israel (1951-1954 and 1957) and South Africa (1974) being most notable. Since the mid-1990s, however, three disturbing epidemiologic trends for $\mathrm{WN}$ virus have emerged: 1) increase in frequency of outbreaks in humans and horses (Romania 1996; Morocco 1996; Tunisia 1997; Italy 1998; Russia, the United States, and Israel 1999; and Israel, France, and the United States 2000); 2) apparent increase in severe human disease (confirmed human infections in recent outbreaks: Romania, 393 cases; Russia
[Volgograd], 942 cases; United States, 62 cases in 1999 and 21 in 2000; Israel, 2 cases in 1999 and 417 in 2000); and 3) high avian death rates accompanying the human outbreaks, in outbreaks in Israel and the United States. Recent outbreaks of WN virus have been accompanied by an apparent evolution of a new WN virus variant. WN virus can be divided genetically into two lineages. Only members of lineage $1 \mathrm{WN}$ viruses have been associated with clinical human encephalitis. Lineage $1 \mathrm{WN}$ viruses have been isolated from Africa, India, Europe, Asia, and North America. Lineage $2 \mathrm{WN}$ viruses are maintained in enzootic foci in Africa and have not been associated with clinical human encephalitis. The close genetic relationship between WN virus isolates from Israel and New York suggests that the virus was imported into North America from the Middle East. The means of its introduction (infected bird, mosquito, human, or another vertebrate host) will likely remain

* The original version of this material was published in Emerging Infectious Diseases 2001; 7(4):611-4.

Corresponding address: Revista Biomédica. Centro de Investigaciones Regionales “Dr. Hideyo Noguchi”, Ave. Itzáes No 490 por 59, C.P. 97000 , Mérida, Yucatán, México.

Accepted July 2, 2001.

This paper is also available at http://www.uady.mx/ biomedic/rb011238.pdf

Vol. 12/No. 3/Julio-Septiembre, 2001 


\section{LR Petersen, JT Roehrig.}

unknown. A striking feature of the initial human epidemic in New York City in 1999 was the high number of avian deaths in the accompanying epizootic, particularly in American Crows (Corvus brachrhynchos) and other corvids. In 2000, 14 mosquito species in five states had evidence of WN virus infection (by culture or nucleic acid amplification). Mosquitoes of the genus Culex are the principal maintenance vector in the Old World. However, which species are most important for transmission to humans or horses remains unknown. Given our incomplete and evolving knowledge of the ecology and public health impact of WN virus in the Americas, as well as the efficacy of control efforts, the virus will remain an important public health challenge in the next decade.

(Rev Biomed 2001; 12:208-216)

Key words: West Nile Virus, Flavivirus, mosquitoes Culex, enzootic diseases, encephalitis, epidemiology.

\section{RESUMEN.}

El Virus del Oeste del Nilo: un patógeno global reemergente.

El reconocimiento del Virus del Oeste del Nilo (VON) en el hemisferio occidental en el verano de 1999 marcó la primera introducción en la historia reciente de un flavivirus del Viejo Mundo al Nuevo Mundo. VON, un miembro de la familia Flaviviradae (género Flavivirus), fue aislado inicialmente en el distrito del oeste del Nilo de Uganda. Desde su aislamiento original, han ocurrido brotes en humanos en forma infrecuente, siendo los más notables los de Israel (1951-1954 y 1957) y Sur África (1974). Sin embargo, desde los mediados de los noventa, tres tendencias epidemiológicas para el VON han emergido: 1) incremento en la frecuencia de brotes en humanos y caballos (Rumania 1996; Marruecos 1996; Turquía 1997; Italia 1998; Rusia, Estados Unidos de NA e Israel 1999; Israel, Francia y Estado Unidos de NA 2000; 2) un incremento aparente en la severidad de la enfermedad en humanos (infecciones humanas confirmadas en brotes recientes: Rumania, 393 casos; Rusia, 942; Estados Unidos de NA, 62 casos en 1999 y 21 en 2000; Israel, 2 casos en 1999 y 417 en 2000); y 3) altas tasas de mortandad en aves acompañando a brotes en humanos en Israel y Estados Unidos de NA. Los recientes brotes del VON se han acompañado por una aparente evolución de una variante viral nueva. El VON puede ser dividido genéticamente en dos linajes. Solamente miembros del linaje $1 \mathrm{WN}$ han sido asociados con encefalitis humana. El linaje $1 \mathrm{WN}$ se ha aislado en África, India, Europa, Asia y Norte América. El linaje $2 \mathrm{WN}$ es mantenido en un foco enzootico en África y no se ha asociado con encefalitis humana. La relación genéticamente estrecha entre los VON aislados en Israel y Nueva York sugieren que el virus fue importado a Norte América del Medio Oriente. Los medios de esta introducción (pájaros infectados, mosquitos, humanos u otros huéspedes vertebrados) permanecen aún desconocidos. Un hallazgo importante en la epidemia inicial en humanos, en Nueva York, en 1999, fue el alto número de muertes de aves, en un brote epizoótico acompañante, particularmente cuervos americanos (Corvus brachehynchos) y otros córvidos. En el año 2000, 14 especies de mosquitos en cinco estados de NA tenían evidencias de infección por el VON (por cultivo o amplificación de ácido nucleico). En el viejo Mundo, los mosquitos del género Culex son los principales vectores. Sin embargo, las especies más importante para la transmisión de humanos y caballos, aún no han sido definidas. Dado nuestro conocimiento incompleto y evolutivo del impacto ecológico y en la salud pública del VON en América, así como la eficacia de las medidas de control, el virus permanecerá como un importante reto de salud pública en la siguiente década. (Rev Biomed 2001; 12:208-216)

Palabras clave: Virus del Oeste del Nilo, Flavivirus, mosquitos Culex, enfermedades enzóoticas, encefalitis, epidemiología.

\section{Revista Biomédica}




\section{West Nile Virus.}

The recognition of West Nile (WN) virus in the Western Hemisphere in the summer of 1999 marked the first introduction in recent history of an Old World flavivirus into the New World $(1,2)$. The United States is not alone, however, in reporting new or heightened activity in humans and other animals, and incursions of flaviviruses into new areas are likely to continue through increasing global commerce and travel. Similar expansion of other flaviviruses has been documented. Dengue viruses, perhaps the most important human flaviviral pathogens, have spread from roots in Asia to all tropical regions (3-5). Japanese encephalitis (JE) virus has recently encroached on the northern shores of Australia and may soon become endemic in that continent (6-9). This issue of Emerging Infectious Diseases focuses on current understanding of the biology, ecology, and epidemiology of WN virus.

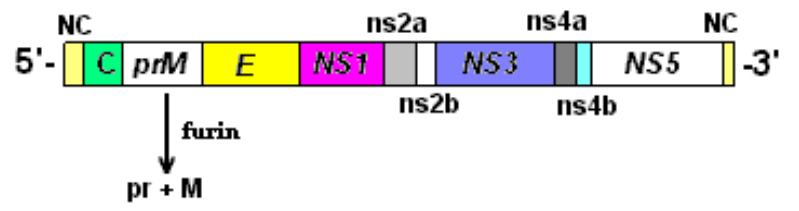

Figure 1.- Genomic structure of flaviviruses. The flavivirus genome is 11,000 to 12,000 nucleotides long. Both the 5'- and 3'- ends contain noncoding (NC) regions. The genome encodes 10 proteins, 3 of which are nonstructural proteins $(\mathrm{C}, \mathrm{M}$, and $\mathrm{E})$, and 7 of which are nonstructural proteins (NS1, NS2a, NS2b, NS3, NS4a, NS4b, and NS5). The M protein is synthesized as a precursor ( $\mathrm{prM}$ ) protein. The prM protein is processed to $\mathrm{pr}+\mathrm{M}$ protein late in the virus maturation by a convertase enzyme (furin).

WN virus, a member of the family Flaviviridae (genus Flavivirus) (10), was first isolated in 1937 in the West Nile district of Uganda (11). Flaviviruses have a 30- to 35-nm

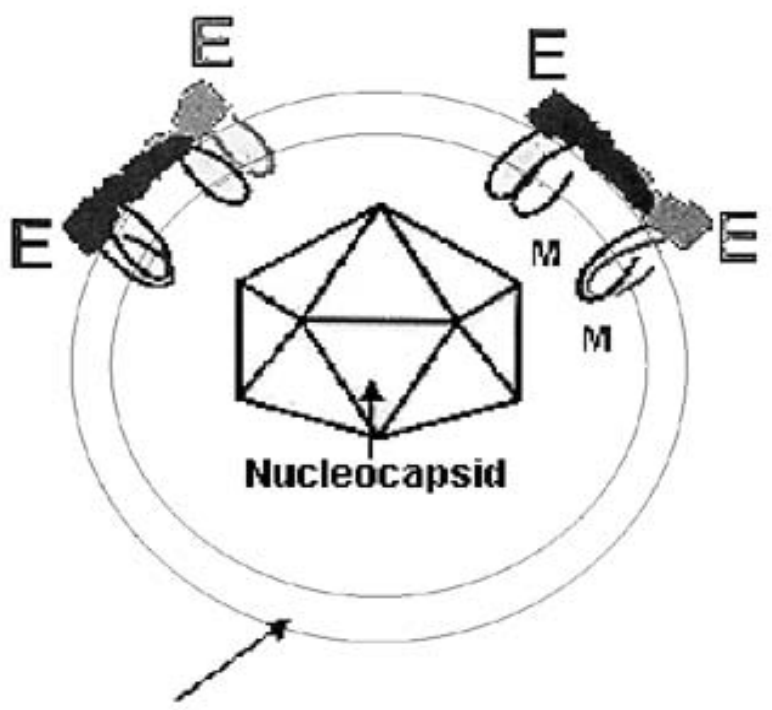

Virion envelope

Figure 2.- Diagram of the flavivirus virion. An icosahedral nucleocapsid (half shown here) encloses the virion RNA. The virion has an envelope redived from the host cell membranes. E-glycoprotein (E), an integral membrane protein, is arranged as homodimers (head-to-tail) and associates with the other integral membrane proteins prM protein (in immature virions).

icosahedral core composed of multiple copies of a 12-kDa capsid protein. The capsid encloses a single-stranded, positive-sense RNA of approximately 12,000 nucleotides (figure 1). The capsid is enclosed in a host cell-derived envelope that has been modified by the insertion of two integral membrane glycoproteins, E (53 $\mathrm{kDa})$ and prM (18-20 $\mathrm{kDa})$. The virion is 45 $\mathrm{nm}$ to $50 \mathrm{~nm}$ in diameter (figure 2). Late in virus maturation, the prM protein is cleaved to $\mathrm{M}$ protein $(8 \mathrm{kDa})$ by a cellular protease, and the $\mathrm{M}$ protein is incorporated into the mature virion. The genome also encodes seven nonstructural proteins (NS1, NS2a, NS2a, NS3, NS4a, NS4b, and NS5) that make up the intracellular replication machinery of the virus. Eglycoprotein, the most immunologically important structural protein, is the viral 


\section{LR Petersen, JT Roehrig.}

hemagglutinin and also mediates virus-host cell binding. It elicits most of the virus neutralizing antibodies. WN virus is a member of the JE virus serocomplex (table) (12), which contains a number of viruses also associated with human encephalitis: JE, St. Louis encephalitis (SLE), Murray Valley encephalitis, and Kunjin (a subtype of WN). All flaviviruses are closely related antigenically, which accounts for the serologic cross-reactions observed in the diagnostic laboratory. Members of the JE complex are even more closely related, often needing specialized tests (e.g., virus neutralization assays) to differentiate the infecting flavivirus (13). Because of the close antigenic relationships between the flaviviruses, acute- and convalescent-phase serum specimens from patients are required to fully assess antibody response. A useful outgrowth of the recent WN virus activity has been the development, standardization, and implementation of rapid techniques for antibody and virus detection (14-16). These rapid, sensitive techniques permitted identification of overwintering mosquitoes in New York City in 2000 and two human WN encephalitis cases in Israel in $1999(17,18)$.

Since the original isolation of $\mathrm{WN}$ virus, outbreaks have occurred infrequently in humans, those in Israel (1951-1954 and 1957) and South Africa (1974) being most notable. Since the mid-1990s, however, three disturbing epidemiologic trends for $\mathrm{WN}$ virus have emerged: 1) increase in frequency of outbreaks in humans and horses (Romania 1996; Morocco 1996; Tunisia 1997; Italy 1998; Russia, the United States, and Israel 1999; and Israel, France, and the United States 2000)(19-23); 2) apparent increase in severe human disease $(2,19,20,22,24,25)$ (confirmed human infections in recent outbreaks: Romania, 393 cases; Russia [Volgograd], 942 cases; United States, 62 cases in 1999 and 21 in 2000; Israel, 2 cases in 1999 and 417 in 2000); and 3) high avian death rates accompanying the human outbreaks, in outbreaks in Israel and the United States.

Recent outbreaks of WN virus have been accompanied by an apparent evolution of a new WN virus variant. WN virus can be divided genetically into two lineages (26-29). Only members of lineage $1 \mathrm{WN}$ viruses have been associated with clinical human encephalitis (the lineage of the WN virus causing the human outbreak in South Africa in 1974 is under contention). Lineage $1 \mathrm{WN}$ viruses have been isolated from Africa, India, Europe, Asia, and North America. In addition, Kunjin virus, an apparent subtype of lineage $1 \mathrm{WN}$ viruses, cocirculates in Australia with a second encephalitis virus member of the JE virus complex, Murray Valley encephalitis virus (26). Lineage $2 \mathrm{WN}$ viruses are maintained in enzootic foci in Africa and have not been associated with clinical human encephalitis. Among lineage $1 \mathrm{WN}$ viruses, the viruses causing the recent human and equine outbreaks throughout Europe and Asia have been most closely related to a $\mathrm{WN}$ virus first isolated in Romania in 1996 (ROM96) and subsequently in Kenya in $1998(25,30,31)$. The WN virus responsible for the U.S. outbreak (NY99) is genetically distinguishable from the ROM96like viruses. The closest relative of NY99 virus was a virus circulating in Israel from 1997 to 2000 (Isr98). Only the United States and Israel have reported illness and death in humans and animals caused by this Isr98/NY99 variant of $\mathrm{WN}$ virus $(18,28)$. The reason for this is not known. The genotype of NY99 WN virus in the United States has remained stable. Very few genomic changes occurred in the NY99 WN virus between the 1999 and $2000 \mathrm{WN}$ virus outbreaks (32; R. Lanciotti, pers. comm.).

\section{Revista Biomédica}


Table

Distribution of Japanese encephalitis (JE) virus serocomplex viruses

\begin{tabular}{llc}
\hline Virus & Abbreviation & Geographic location \\
\hline $\begin{array}{l}\text { Cacipacore } \\
\text { Koutango } \\
\text { Japanese } \\
\text { encephalitis }\end{array}$ & KOC & $\begin{array}{l}\text { South America } \\
\text { Africa }\end{array}$ \\
$\begin{array}{l}\text { Murray Valley } \\
\text { encephalitis }\end{array}$ & MVE & Asia, Oceania, Australia \\
$\begin{array}{l}\text { Alfuy } \\
\text { St. Louis } \\
\text { encephalitis }\end{array}$ & ALF & Australia \\
$\begin{array}{l}\text { West Nile } \\
\text { encephalitis }\end{array}$ & WN & Australia \\
$\begin{array}{l}\text { Kunjin } \\
\text { Yaounde }\end{array}$ & KUN & Africa, Asia, Europe, North America \\
\hline
\end{tabular}

${ }^{a} \mathrm{JE}$ virus has occasionally been introduced into Australia. Classification from (12).

The $2000 \mathrm{WN}$ virus outbreak in humans and birds in Israel was caused by cocirculation of both the ROM96 and the Isr98 variants of WN virus (33; C. Banet, manuscript in preparation). Although these are the first reports of two genetic variants of WN virus causing a single WN encephalitis outbreak in humans and birds, similar mixed human flavivirus outbreaks have been documented for dengue virus (34).

The close genetic relationship between WN virus isolates from Israel and New York suggests that the virus was imported into North America from the Middle East. The means of its introduction (infected bird, mosquito, human, or another vertebrate host) will likely remain unknown. A striking feature of the initial human epidemic in New York City in 1999 was the high number of avian deaths in the accompanying epizootic, particularly in American Crows (Corvus brachrhynchos) and other corvids $(35,36)$. Subsequent work demonstrating near $100 \%$ death rates among experimentally infected American Crows with NY99 WN virus has confirmed this observation (R. McLean, pers. comm.). Although one early study showed high death rates among Egyptian Hooded Crows (Corvus corone) and House Sparrows (Passer domesticus) experimentally infected with the prototype Egypt $101 \mathrm{WN}$ virus strain (37), the epizootic in Israel in 1997 to 2000 was the first in the Old World demonstrating high avian death rates (38). Whether high avian death rates in the United States are due to higher virulence of the circulating strains or to higher susceptibility in North American birds requires further evaluation.

High avian death rates during the 1999 epizootic in the New York City area prompted an avian mortality surveillance system to track the spread of WN virus in the eastern and southern United States. Surveillance showed expansion of viral activity to 12 states in 2000 , extending from the Canadian border to North Carolina, a distance of $900 \mathrm{~km}$ (39). Pronounced northward spread of the virus from New York City was noted in the late spring and early summer and southward spread in the late summer and fall--a pattern consistent with bird migration. Through 2000, avian mortality rate surveillance has documented WN virus infection in 76 North American native and captive bird species. Although American Crows were by far the most commonly identified species, this may reflect the lethality of infection in this species, rather than its importance as a reservoir host.

Despite the substantial geographic expansion of WN virus activity documented by avian mortality surveillance in 2000 , human infections were noted only in New York City and surrounding counties in New Jersey and Connecticut (39). Ten of the 21 infected persons identified in 2000 lived on Staten Island, the only part of New York City without documented WN virus infections in humans in 1999. The reason that the 2000 human epidemic remained focal despite a widely geographically expanding epizootic is unknown. Extensive spring and early summer larval mosquito control efforts in urban areas of the Northeast likely contributed to decreased human exposure to mosquitoes.

In addition to high mortality rates of $5 \%$ to $14 \%$ 


\section{LR Petersen, JT Roehrig.}

among persons with neurologic symptoms in the recent U.S., Romanian, Russian, and Israeli outbreaks, other clinical aspects (e.g., profound motor weakness and infrequency of skin rash and lymphadenopathy) differ from those of earlier outbreaks $(19,20,22,25,39,40)$. Serologic surveys accompanying the Romanian (1996) and two U.S. outbreaks (1999 and 2000) indicated that severe neurologic illness developed in $<1 \%$ of persons infected with WN virus, with systemic febrile illness developing in approximately $20 \%$ of those infected $(40,41)$.

In the United States in both 1999 and 2000, infections in humans peaked in August and in horses in September $(39,42)$, suggesting either different mosquito species transmitting the virus to humans and horses or temporal differences in exposure to the same species. In 2000, 14 mosquito species in five states had evidence of WN virus infection (by culture or nucleic acid amplification) (39). Since mosquitoes of the genus Culex are the principal maintenance vectors in the Old World, not surprisingly, Cx. pipiens and Cx. restuans--common, ornithophilic maintenance vectors for SLE in the northeastern United States (43)--were by far the most frequently identified species with WN virus in 2000 (39). However, which species are most important for transmission to humans or horses remains unknown. Extensive mosquito collections from Connecticut and New York State indicated that Cx. pipiens was present in high numbers and had high WN virus infection rates in early August, coinciding with a subsequent peak in human disease in the New York City area $(44,45)$. One important observation was the high WN virus infection rates in and abundance of $\mathrm{Cx}$. salinarius mosquitoes on Staten Island in 2000, which temporally coincided with the human outbreak (46). This species indiscriminately feeds on both birds and mammals and readily bites humans.

Experience with WN virus in the Old World and SLE virus in the Americas may provide clues to the eventual outcome of $\mathrm{WN}$ virus in the
Americas. The broad geographic distribution of WN virus in Africa, Europe, the Middle East, and western Asia suggests potential for wide geographic distribution in the Americas. The principal mosquito vectors and avian host species for SLE virus vary regionally; the broad range of mosquito vectors and avian host species for $\mathrm{WN}$ virus in the Old World also suggests that a similar pattern can occur in the Americas for WN virus (23). Further study of the ecology and epidemiology of WN virus in areas where the virus has been endemic for a long time (e.g., the Nile Delta in Egypt) will provide additional clues about what can be expected in the Americas.

Outbreaks caused by WN and SLE viruses have been difficult to predict, in part because of our incomplete knowledge of the viruses' complex ecology. Weather data suggest that hot, dry summers may promote human outbreaks caused by these two viruses $(25,40,47,48)$. The mean July temperature in the New York City area in 1999 was among the highest on record, while 2000 was comparatively cool. However, climate and weather influence mosquito populations and arboviral recrudescence in complex ways; simple generalizations about weather have had poor predictive value for SLE forecasting and will likely be equally unpredictive for WN virus forecasting in any given area $(48,49)$.

In the United States, first attempts have been made to predict WN virus human epidemics in a county on the basis of avian mortality data (50); efforts to interpret avian mortality or other surveillance data at a more local level for more focused emergency mosquito control are at an even earlier stage of development $(46,51)$. To prevent WN virus infection in humans, extensive early season larval control has been recommended and undertaken, as have the development and dissemination of public health messages for reducing personal exposure to mosquito bites (52). The efficacy and cost-effectiveness of these prevention measures, along with application of pesticides to control adult mosquitoes, require

\section{Revista Biomédica}




\section{West Nile Virus.}

further evaluation. These evaluations are likely to be hindered by the sporadic nature of human WN epidemics. Given our incomplete and evolving knowledge of the ecology and public health impact of $\mathrm{WN}$ virus in the Americas, as well as the efficacy of control efforts, the virus will remain an important public health challenge in the next decade.

\section{REFERENCES.}

1.- Asnis DS, Conetta R, Teixeira AA, Waldman G, Sampson BA. The West Nile Virus outbreak of 1999 in New York: the Flushing Hospital experience. Clin Infect Dis 2000;30:413-8.

2.- Nash D, Mostashari F, Fine A, Miller J, O'Leary D, Murray $\mathrm{K}$, et al. Outbreak of West Nile virus infection, New York City area, 1999. N Engl J Med 2001;344:180714.

3.- Gubler DJ. Dengue and dengue hemorrhagic fever in the Americas. P R Health Sci J 1987;6:107-11.

4.- Gubler DJ, Clark GG. Dengue/dengue hemorrhagic fever: the emergence of a global health problem. Emerg Infect Dis 1995;1:55-7.

5.- Gubler DJ. The global pandemic of dengue/dengue haemorrhagic fever: current status and prospects for the future. Ann Acad Med Singapore 1998;27:227-34.

6.- Ritchie SA, Phillips D, Broom A, Mackenzie J, Poidinger M, van den Hurk A. Isolation of Japanese encephalitis virus from Culex annulirostris in Australia. Am J Trop Med Hyg 1997;56:80-4.

7.- Hanna JN, Ritchie SA, Phillips DA, Shield J, Bailey MC, Mackenzie JS, et al. An outbreak of Japanese encephalitis in the Torres Strait, Australia, 1995. Med J Aust 1996;165:256-60.

8.- Hanna JN, Ritchie SA, Phillips DA, Lee JM, Hills SL, van den Hurk AF, et al. Japanese encephalitis in north Queensland, Australia, 1998. Med J Aust 1999;170:5336.

9.- Mackenzie JS, Broom AK, Hall RA, Johansen CA, Lindsay MD, Phillips DA, et al. Arboviruses in the Australian region, 1990 to 1998 . Commun Dis Intell 1998;22:93-100.
10.- Gubler DJ, Roehrig JT. Togaviridae and Flaviviridae. In: Collier L, Balows A, Sussman M, editors. Topley and Wilson's microbiology and microbial infections. London: Arnold Publishing; 1999. p. 579-600.

11.- Smithburn KC, Hughes TP, Burke AW, Paul JH. A neurotropic virus isolated from the blood of a native of Uganda. Am J Trop Med 1940;20:471-92.

12.- Heinz FX, Collett MS, Purcell RH, Gould EA, Howard CR, Houghton M, et al. Family: Flaviviridae. In: Van Regenmortel MHV, Fauquet CM, Bishop DHL, Carstens EB, Estes MK, Lemon SM, et al., editors. Virus taxonomy: classification and nomenclature of viruses. 7th Report of the International Committee on Taxonomy of Viruses. San Diego: Academic Press; 1999. p. 859-78.

13.- Roehrig JT. Arboviruses. In: Specter S, Hodinka RL, Young SA, editors. Clinical virology manual. 3rd ed. Washington: American Society for Microbiology; 1999. p. 356-73.

14.- Johnson DJ, Ostlund EN, Pedersen DD, Schmitt BJ. Detection of North American West Nile Virus in animal tissue by a reverse transcription-nested polymerase chain reaction assay. Emerg Infect Dis 2001;7. (This issue)

15.- Lanciotti RS, Kerst AJ, Nasci RS, Godsey MS, Mitchell CJ, Savage HM, et al. Rapid detection of West Nile virus from human clinical specimens, field-collected mosquitoes, and avian samples by a TaqMan reverse transcriptase-PCR assay. J Clin Microbiol 2000;38:4066-71.

16.- Briese T, Glass WG, Lipkin WI. Detection of West Nile virus sequences in cerebrospinal fluid. Lancet 2000;355:1614-5.

17.- Nasci RS, Savage HM, White DF, Miller JR, Cropp $\mathrm{BC}$, Godsey MS, et al. West Nile virus in overwintering Culex mosquitoes, New York City, 2000. Emerg Infect Dis 2001;7. (This issue)

18.- Giladi M, Metzkor-Cotter E, Martin DA, SiegmanIgra Y, Korczyn AD, Rosso R, et al. West Nile encephalitis in Israel, 1999: The New York connection. Emerg Infect Dis 2001;7. (This issue)

19.- Weinberger M, Pitlik SD, Gandacu D, Lang R, Nassar F, Ben David D, et al. West Nile fever outbreak, Israel, 2000: Epidemiologic aspects. Emerg Infect Dis 2001;7. (This issue)

20.- Chowers MY, Lang R, Nassar F, Ben-David D, Giladi Vol. 12/No. 3/Julio-Septiembre, 2001 


\section{LR Petersen, JT Roehrig.}

M, Rubinshtein E, et al. Clinical characteristics of the West Nile Fever outbreak, Israel, 2000. Emerg Infect Dis 2001;7. (This issue)

21.- Murgue M, Murri S, Zientara S, Durand B, Durand J-P, Zeller H. West Nile outbreak in horses in Southern France, 2000: the return after 35 years. Emerg Infect Dis 2001;7. (This issue)

22.- Weiss D, Carr D, Kellachan J, Tan C, Phillips M, Bresnitz E, et al. Clinical findings of West Nile virus infection in hospitalized patients, New York and New Jersey, 2000. Emerg Infect Dis 2001;7. (This issue)

23.- Hub lek Z, Halouzka J. West Nile fever--a reemerging mosquito-borne viral disease in Europe. Emerg Infect Dis 1999;5:643-50.

24.- Cernescu C, Ruta SM, Tardei G, Grancea C, Moldoveanu L, Spulbar E, et al. A high number of severe neurologic clinical forms during an epidemic of West Nile virus infection. Rom J Virol 1997;48:13-25.

25.- Platonov AE, Shipulin GA, Shipulina OY, Tyutyunnik EN, Frolochkina TI, Lanciotti RS, et al. Outbreak of West Nile virus infection, Volgograd Region, Russia, 1999. Emerg Infect Dis 2001;7:128-32.

26.- Scherret JH, Poidinger M, Mackenzie JS, Broom AK, Deubel V, Lipkin I, et al. The relationships between West Nile and Kunjin viruses. Emerg Infect Dis 2001;7. (This issue)

27.- Berthet FX, Zeller HG, Drouet MT, Rauzier J, Digoutte JP, Deubel V. Extensive nucleotide changes and deletions within the envelope glycoprotein gene of Euro-African West Nile viruses. J Gen Virol 1997;78:2293-7.

28.- Lanciotti RS, Roehrig JT, Deubel V, Smith J, Parker $\mathrm{M}$, Steele K, et al. Origin of the West Nile virus responsible for an outbreak of encephalitis in the northeastern United States. Science 1999;286:2333-7.

29.- Jia XY, Briese T, Jordan I, Rambaut A, Chi HC, Mackenzie JS, et al. Genetic analysis of West Nile New York 1999 encephalitis virus. Lancet 1999;354:1971-2.

30.- Savage HM, Ceianu C, Nicolescu G, Karabatsos N, Lanciotti R, Vladimirescu A, et al. Entomologic and avian investigations of an epidemic of West Nile fever in Romania in 1996, with serologic and molecular characterization of a virus isolate from mosquitoes. Am J Trop Med Hyg 1999;61:600-11.

\section{Revista Biomédica}

31.- Miller BR, Nasci RS, Godsey MS, Savage HM, Lutwama $\mathrm{JJ}$, Lanciotti RS, et al. First field evidence for natural vertical transmission of West Nile virus in Culex univittatus complex mosquitoes from Rift Valley province, Kenya. Am J Trop Med Hyg 2000;62:240-6.

32.- Ebel GD, Dupuis AP II, Ngo K, Nicholas D, Kauffman $\mathrm{E}$, Jones SA, et al. Partial genetic characterization of West Nile virus strains, New York State, 2000. Emerg Infect Dis 2001;7. (This issue)

33.- Hindiyeh M, Shulman LM, Mendelson E, Weiss L, Grossman Z, Bin H. Isolation and characterization of West Nile virus from the blood of viremic patients during the 2000 outbreak in Israel. Emerg Infect Dis 2001;7. (This issue)

34.- Gubler DJ, Kuno G, Sather GE, Waterman SH. A case of natural concurrent human infection with two dengue viruses. Am J Trop Med Hyg 1985;34:170-3.

35.- Eidson M, Komar N, Sorhage F, Nelson R, Talbot T, Mostashari $\mathrm{F}$, et al. Crow deaths as a sentinel surveillance system for West Nile virus in the northeastern United States, 1999. Emerg Infect Dis 2001;7. (This issue)

36.- Steele KE, Linn MJ, Schoepp RJ, Komar N, Geisbert TW, Manduca RM, et al. Pathology of fatal West Nile virus infections in native and exotic birds during the 1999 outbreak in New York City, New York. Vet Pathol 2000;37:208-24.

37.- Work TH, Hurlbut HS, Taylor RM. Indigenous wild birds of the Nile Delta as potential West Nile virus circulating reservoirs. Am J Trop Med Hyg 1955;4:87288.

38.- Swayne DE, Beck JR, Smith CS, Shieh W-J, Zaki SR. Fatal encephalitis and myocarditis in young domestic geese (Anser anser domesticus) caused by West Nile virus. Emerg Infect Dis 2001;7. (This issue)

39.- Marfin AA, Petersen LR, Eidson M, Miller J, Hadler J, Farello C, et al. Widespread West Nile virus activity, eastern United States, 2000. Emerg Infect Dis 2001;7. (This issue)

40.- Tsai TF, Popovici F, Cernescu C, Campbell GL, Nedelcu NI. West Nile encephalitis epidemic in southeastern Romania. Lancet 1998;352:767-71.

41.- Centers for Disease Control and Prevention. Serosurveys for West Nile virus infection--New York and 
West Nile Virus.

Connecticut Counties, 2000. MMWR Morb Mortal Wkly Rep 2001;50:31-9.

42.- Centers for Disease Control and Prevention. Update: West Nile virus activity--Eastern United States, 2000. MMWR Morb Mortal Wkly Rep 2000;49:1044-7.

43.- Mitchell CJ, Francy DB, Monath TP. Arthropod vectors. In: Monath TP, editor. St. Louis encephalitis. Washington: American Public Health Association; 1999. p. 313-79.

44.- Andreadis TG, Anderson JF, Vossbrinck CR. Mosquito surveillance for West Nile virus in Connecticut, 2000: Isolation from Culex pipiens, Cx. restuans, Cx. salinarius, and Culiseta melanura. Emerg Infect Dis 2001;7. (This issue)

45.- White DJ, Kramer LD, Backenson PB, Lukacik G, Johnson G, Oliver J, et al. Mosquito surveillance and polymerase chain reaction detection of West Nile virus, New York State. Emerg Infect Dis 2001;7. (This issue)

46.- Kulasekera V, Kramer L, Nasci RS, Mostashari F, Cherry B, Trock SC, et al. West Nile virus infection in mosquitoes, birds, horses, and humans, Staten Island, New York, 2000. Emerg Infect Dis 2001;7. (This issue)

47.- Han LL, Popovici F, Alexander JP, Laurentia V, Tengelsen LA, Cernescu C, et al. Risk factors for West Nile virus infection and meningoencephalitis, Romania, 1996. J Infect Dis 1999;179:230-3.

48.- Reiter P. Weather, vector biology and arboviral recrudescence. In: Monath TP, editor. The arboviruses: epidemiology and ecology. Boca Raton (FL): CRC Press; 1999. p. 245-55.

49.- Reiter P. Climate change and mosquito-borne disease. Environ Health Perspect 2001;109:141-61.

50.- Eidson M, Miller J, Kramer L, Cherry B, Hagiwara Y, West Nile Virus Bird Mortality Analysis Group. Dead crow densities and human cases of West Nile virus, New York State, 2000. Emerg Infect Dis 2001;7. (This issue)
51.- Hadler J, Nelson R, McCarthy T, Andreadis T, Lis MJ, French R, et al. West Nile virus surveillance in Connecticut in 2000: An intense epizootic without high risk for severe human disease. Emerg Infect Dis 2001;7.

52.- Centers for Disease Control and Prevention. Epidemic/ epizootic West Nile virus in the United States: revised guidelines for surveillance, prevention and control. Available at URL: http://www.cdc.gov/ncidod/dvbid/ westnile/publications.htm 